\title{
Examining Female School Leaders' Experience with Technology in Online Learning: insights from Indonesia
}

\author{
$1^{\text {st }}$ Dion Ginanto ${ }^{1}, 2^{\text {nd }}$ Atika Atika ${ }^{2}, 3^{\text {rd }}$ Ayub Mursalin ${ }^{3}, 4^{\text {th }}$ Baharudin Baharudin $^{4}$, \\ $5^{\text {th }}$ Muhammad Gazali ${ }^{5}, 6^{\text {th }}$ M. Husnul Abid ${ }^{6}$ \\ \{dionefrijum@uinjambi.ac.id ${ }^{1}$, atika@uinjambi.ac.id², ayubmursalin@uinjambi.ac.id ${ }^{3}$, \\ baharudin@uinjambi.ac.id ${ }^{4}$, gazali@uinjambi.ac.id ${ }^{5}$, abidisme@uinjambi.ac.id $\left.{ }^{6}\right\}$
}

UIN Sulthan Thaha Saifuddin Jambi 1, 2, 3, 4, 5,6

\begin{abstract}
This paper examines female school leaders' experience in using technology in online learning at schools in rural areas in Jambi Province, Indonesia. We used semistructured interviews and reflective journals to investigate female school leaders' in leading the learning process during the pandemic. There were five female school leaders from rural areas in Jambi Province, Indonesia participated in this study. While the previous studies focus on examining teachers' online learning experience, this study emphasizes more on female school administrators in rural areas adjusting to the use of technology in the teaching and learning process. This study found that most of the school leaders in rural areas are in great need of attention on facilities and professional development focusing on the use of media and technology both in teaching and managing the school during the pandemic. The current study also argues that collaboration among teachers is imperative to make sure that the teachers and administrators are equipped with the knowledge and skills of how to use technology that improves the quality of education during online learning. This article contributes to both policymakers and practitioners in understanding the use of technology and leadership in online learning in rural areas.
\end{abstract}

Keywords: Female leadership, school principal, education, technology, online learning

\section{Introduction}

While research suggests that technology usage can enhance the teacher's and student's performance [1], there are still few reports that school leaders are capable enough of embedding technology into their schools' instructional practice [2]. School leaders, regardless of male or female, need to accelerate, improvise and adjust to the massive change in the educational world due to the Covid-19 pandemic [3][4]. There are some studies, however, reporting that female leaders are seen differently in both developed and developing countries [5], [6], [7], [8] [9].

With the rapid change of industry, global world, as well as the worldwide pandemic; the school administrators, both male and female leaders, have a significant role in ensuring teachers, staff, and students are equipped with the best skills and knowledge of technology [10]. That being said, teachers will gradually leave their old-fashioned teaching in the classroom. With today's world as well as the pandemic that struck all educational settings, teaching and learning will automatically be conducted with technology [11]. The problem, however, not all schools, especially in Indonesian rural areas context are ready with the rapid change of the use 
of technology during online learning. This study, therefore, aims in examining the perspectives of female leaders in rural areas in leading their schools during the pandemic.

\subsection{School Leadership and Technology}

In the Industrial Revolution 4.0, digital technology became the primary key in carrying out various organizational activities. Our today's world combines automation technology with cyber technology. In this era, the industry began to touch the virtual world through human connectivity, machines, and data, which can be accessed anywhere, otherwise known as the Internet of Things (IoT) [12]. The technology will help solve problems and track processes and increase productivity in business and manufacturing at scales aimed at improving the productivity of human life. Educational institutions have become one of the organizations that need to utilize such information technology.

Leadership relates to qualities and attitudes inspiring others to carry out a job and advance the school organization. Leadership in educational institutions is deemed necessary in influencing, encouraging, guiding, directing, and mobilizing others that have to do with the implementation and development of education and teaching or training so that all activities can run effectively and efficiently, which in turn will achieve the educational and learning goals that have been set [13].

The Covid-19 pandemic has had a significant impact on education by nearly closing many schools in the world [14]. The first thing that was successfully done to overcome the school's closure was to protect the health and safety of the school residents, one of which was by carrying out distance learning. This is where the significant role is to keep his leadership well amid a crisis like this. Principals must implement "crisis management", which is the process of preparing and managing emergency or unexpected conditions that affect students, teachers, staff, and stakeholders [15], [3]. The use of digital technology is one of the strategies that can be applied in schools to support learning to teach remotely. Many schools are ultimately transforming digitally by using web-based applications to facilitate learning, meeting, and managerial coordination when working from home. To make sure that the school principals can perform effectively and efficiently, they need to be assisted with extra workshops or professional development [16].

\subsection{School Leadership and Gender}

In the traditional view, women are identified with weak, subtle, and emotional figures, while men are portrayed as dashing, courageous, and rational. This view has positioned women as human beings that seem to be protected and always dependent on men. This makes it rare for a woman to appear as a leader because she is sidelined by male domination with her chauvinistic male.

Nowadays, women's leadership in educational institutions has been talked about by academics. The low representation of women in key leadership positions led to more research on similar themes, particularly on the inhibitory factors, challenges, and structures, and agencies surrounding the women [5], [6], [7], [8]. In developed countries such as Australia, the USA, and the UK, the disparity in gender-based leadership percentage is still significant. Facing the 21st century, the challenge of women becoming leaders is growing. Winchester et al [17] underline the need for policies on the promotion of positions for women.

Similar problems are experienced by women in educational institutions in developing countries. The leadership of the female principle is also still the center of attention of academics 
[9]. Potential female teachers began to occupy the position of principal. It certainly raises a paradigm in organizing with the doubt about the quality of women's leadership, especially to improve the quality of education in the institutions they lead. This condition arises because of the view that women are weak figures in decision-making. The labeling will undoubtedly give rise to many stereotypes constructed by society due to social relations about the differences between men and women that seem to be natural.

Many factors influence a woman's career achievement in a leadership position, including self-will, strong support from the family, and luck at the time of the election [18]. On the other hand, Shahtalebi et al. [19] affirm that the success factor of women in careers in educational institutions is in the presence of positive views of those around them, family factors, community views, management, ability to lead, and personal views and characteristics of women themselves.

The path taken by women in leadership undergoes many "twists and turns" due to the many challenges that can be predicted before and not expected at all [18]. There are at least three main challenges that women often face in their leadership positions: social, cultural, and psychological difficulties. Prejudice is the most ingrained challenge faced by women. Categories about leadership qualities that constantly refer to men make female leadership looked at in the eye. For example, women are considered more communal: affectionate, helpful, friendly, kind, sympathetic, sensitive, gentle, and soft-spoken are considered not adequate leadership characteristics [19]. Organizational problems and masculine culture in work become obstacles for women to develop their careers [20].

The media has so far reported that women leaders worldwide are managing the Covid-19 situation better than their male colleagues, including responding faster and communicating better about pandemic measures [21]. Similarly, a study revealed that female principals could do more by successfully bringing the school they lead to achieve further than the school rankings [22].

\subsection{Fostering an Effective Online Learning in Rural Areas}

The enactment of online learning by the government requires all teaching and learning activities to be conducted from home. The implementation of online education is carried out as one of the efforts to continue to realize educational goals in Indonesia during the covid19 pandemic and efforts to prevent the spread of the covid-19 virus. Covid-19 pandemic makes the learning system in schools forced to change drastically from face-to-face meetings to online learning. The implementation of this learning takes place from elementary school to college level.

Compared to schools in suburban and urban areas, schools in rural areas need to work harder due to the minimum amount of support, resources, and technologies [23].

There are some of the most prominent obstacles faced by students [24], namely 1) changes in habits that occur in students and teachers who initially receive well with considerable enthusiasm because learning activities are done at home [25]; 2) the intensity of the teacher in delivering material in one of the subjects becomes reduced and less effective. This is because not all subjects could be taught effectively online [25]; 3) the lack of internet network infrastructure in various corners of the country, which is one of the supporting facilities for the continuity of online learning instead of face-to-face learning [25]; and 4) there are still many students who do not have gadgets that are compatible with online learning. 


\section{Methodology}

Our study examines the female school leaders' experience in online learning during the pandemic. We analyzed their leadership role in managing the technology used in the teaching and learning process. We used semi-structured interviews [26] and recruited five high school principals in rural areas in Jambi Province Indonesia: (1) Mrs. Sas, a high school principal; (2) Mrs. Dewi, an elementary school principal; (3) Mrs. Febri, a high school principal; (4) Mrs. Dina, an elementary school principal; (5) Mrs. Riska, a high school principal; (6) Mrs. Endang, a middle school principal.

Rural school principals in this study are defined as those who work in an area with challenges and barriers due to the area's remoteness [27]. These five school principals are varied regarding the types of school, length of work, distance to the capital city, and the level of educational background. The varied backgrounds of these school principals resulted in a wide range of responses to the study.

We used an in-depth narrative case study [28] to understand better school principals' experience in leading a school in rural areas when at the same time, they need to make sure that students learn. The participants willingly decided to participate after we explained the purpose, risks, and benefits of participation in this study. We also guaranteed them that their identity would be kept confidential by giving pseudonyms in our reports.

We recorded, created journals, transcribed all of the information, and coded and analyzed in [29]. At the start, we used open coding to figure out the answers to our main research question and additional themes outside the study. We then moved the coded data into a matrix to find the pattern and analyze them in several researchers' team meetings [30]. Finally, we also conducted member checks with all ten participants to ensure the data's accuracy and validity.

\section{Result and Discussion}

This current study aimed to evaluate the experiences of female school leaders in employing technology for online learning in schools. Most of the school leaders in this study were having a challenging time during the COVID-19. On the one hand, they need to make sure that the students learn, but at the same time, they have difficulties in accessing the internet and sources. Therefore, they need some support from the government, including professional development focusing on the use of technology and media in teaching online. The school leaders in this study also highlighted the important factors that can increase students' learning during the pandemic era such as creativity, innovation, and collaboration.

\subsection{We are from rural areas we don't know how to use technology}

Similar to the previous studies [23], that school in rural areas faces extra challenges and barriers compared to their urban or suburban counterparts; this study also found that the female leaders in rural areas in Jambi Province also face a challenge in the use of technology for online learning. Participants in this study highlighted the challenging situation in which they are not familiar with the technology.

Their rural area situation has so far hindered them from the use of modern devices for learning. Mrs. Sas stated, "This is because our school is in a very rural area. We are not familiar with smartphones or laptops. Yes, we have smartphones, but so far, we only use them for 
communication and social media." Similarly, Mrs. Dewi emphasized the scarcity of internet access in her area: "The problem is that my students have problems both with the availability of internet access as well as their capability to purchase the internet data. But at the same time, we need to teach them, make sure that they have something to learn."

Finally, Mrs. Febri admitted that most of the people in the building are not familiar with the use of technology in teaching students remotely, "We are from rural Areas we don't know how to use technology." Finally, Mrs. Dina and Mrs. Dewi stated that due to the lack of facilities the schools provide and the scarcity of internet access, and the ability to purchase internet data, the best teaching application that the school uses is WhatsApp. According to Mrs. Dina and Mrs. Dewi, WhatsApp is the most friendly, cheap, and af

\subsection{We need Professional Development Focus on Technology}

Mrs. Febri requested the government train their teachers that focus on technology, "All of us were new in teaching online. We need IHT (in-house training) focusing on the use of media and technology in online learning." Similarly, Mrs. Sas was also hoping that the government invests more in teachers, especially as the transition of the Industry revolution 5.0 is on its way. She stated, "We need leadership skills and professional development in the era of both pandemic and Industry revolution 5.0." While the role of government is vital for helping teachers with professional development [15], [3], Mrs. Sas did not want to wait; instead, she initiated a professional learning community in her building, "Even though the government has not yet trained us with the use of technology in teaching; and although I am a female leader, me and our staff in this building have conducted the digital transformation's training by using a webbased application to facilitate learning, meeting, and other managerial activities even when we are demanded to work from home." In addition to professional development for teachers, Mrs. Dina also argued that parents need also be trained on using technology for online learning: "We hope that the government holds a workshop for our parents and teachers which focus on the use of technology in online learning so parents and teachers can effectively help students in online learning."

\subsection{We need a workshop on how to use media in teaching}

School leaders in this study need training on using technology for online learning, but they also need workshops focused on how to use media to increase the quality of online teaching. Mrs. Febry stated, "Superintendent and or local government officials need to come and train our teachers, including me on how to create a learning video or any kind of interesting teaching media. They also need to upgrade our knowledge and skills on how to create online questions for the sake of evaluation and assessment." Having a variety of media in teaching can minimize students' boredom when they conduct their studies from home. Mrs. Riska mentioned, "I want my teachers to maximize their effort in using technology and media in teaching. We want simple and meaningful learning activities, not just give a bunch of homework to our students." When the students are engaged in learning, students will more likely achieve more. Mrs. Endang stated in our interview: "School leaders and teachers need to always innovate on models, methods, and approach in online learning; so, we can increase students' achievement even though we work and learn from home." Finally, by having sufficient training on how to create teaching media for online learning, teachers will be more creative and when teaching, they do not merely give a bunch of homework for students. "We want our teachers to be more creative, so even though they meet online, we want to make sure that our students do not feel bored. We do not want our 
teachers to give us so much homework. We want to educate our students' soft skills and character during the pandemic. So, we need a workshop on how to use media in teaching" (Mrs. Sas, in our interview). The findings on the need for professional development on creating media for online learning is in line with the previous studies that the school principals and teachers need to be creative to meet the needs of the students and parents [25], [13], [16].

\subsection{Collaboration is the Key for the Success of Online Learning}

To answer the reports and studies that teachers and school leaders especially in rural areas are less capable of using technology and media in teaching online [2], [31], [32]; the participants of this current study believe that collaboration is one the components that lead to the success of online learning. The participants of the study believe that collaboration is the key for schools in rural areas when it comes to online learning. The limitations and shortcomings their schools have could be minimized if they work collaboratively with each other. Bu Riska asserted the importance of collaboration during our interview: "We collaborate to assist each other, especially how to create useful learning resources for our students." In addition, the schools also need to empower the staff in the building who has strong ability in IT (information and technology) to help assist others. Mrs. Riska argued, "I always work closely with our IT support in our school. This is important, so I can make sure that all teachers are well-informed in terms of the use of technology in teaching." Similarly, Mrs. Dewi stated in the interview, "So, I identify the best teachers who can use technology. Then we request him to help other teachers who are in need with technology or media during online learning." Further, Mrs. Dewi asserted that collaboration among teachers and staff are believed to increase student's life skills, as mentioned in the interview: "During the pandemic, I want to maximize the collaboration among teachers, parents, and the community, so we can ensure that students could increase their life skills and literacy skills".

\section{Conclusion}

Leadership is a journey, including for women. Being a female leader in a rural area during Covid-19 required extra focus and energy to ensure that although there is a shortcoming in internet access and professional development on how to use technology in online learning, students remain learning. This study is in line with the previous research that gender is not deemed as an obstacle for female leaders to accelerate and innovate. However, the government needs to invest more in the facilities so the teachers and students could benefit from them. Besides, the government needs to also help teachers and school leaders by holding ongoing professional development on how to lead and teach during the pandemic.

This current study shows that collaboration is one crucial factor that can increase teaching quality, especially when using media and technology in online learning. By having a good quality of instruction, the teachers would no longer give their students a heavy homework load. Instead, with a suitable approach in teaching, the students will engage in learning even though it is conducted online.

This study provides recommendations for policymakers that despite the creativity the female leaders shown in this study, most of the school leaders have a high expectation for both local and central government to (1) pay more attention to leaders in a rural area; (2) equip 
teachers and leaders in a rural area with the professional development especially on the use of media and technology in online learning; (3) give more subsidy for both teachers and students with the internet data especially for schools in a rural area.

\section{References}

[1] O’Dwyer, L. M., Russell, M., \& Bebell, D. J: Identifying teacher, school and district characteristics associated with elementary teachers' use of technology: A multilevel perspective. Education Policy Analysis Archives, 12(48) (2004)

[2] Gosmire, D., \& Grady, M. L: A bumpy road: Principal as technology leader. Principal Leadership, 7(6), p. 15-21). National Association of Secondary Principals. Reston, VA (2007)

[3] Hudson, L., Mahendrarajah, S., Walton, M., Pascaris, M.J., Melim, S., Rutterberg-Rozen, R.: Leadership in education during COVID-19: Learning and growth through a crisis. Journal of Digital and Technology. (2020)

[4] Harris, A., \& Jones, M: COVID-19 school leadership in disruptive times. School Leadership and Management, 40(4), 243-247. (2020)

[5] Levitt, D. H: Women and leadership: A developmental paradox?” ADULTSPAN Journal, Vol 9 No 2. (2010)

[6] Jay, J. K. \& Morgan, H. J: Strategies for women in leadership to advance their careers, Employment Relation Today.n.d. (2016).

[7] Sinclair, A: Journey around leadership, Discourse: Studies in the Cultural Politics of Education, Vol 25 no 1. (2004).

[8] Sinclair, A: SeducinglLeadership: Stories of leadership development. Gender, Work, and Organization Vol 16 no 2. (2009).

[9] Wardani, A., Munandar, M. A., \& Makmuri: Peran Kepemimpinan Kepala Sekolah Perempuan Terhadap Motivasi Kerja Guru (Studi di SMAN 12 Semarang).” Unnes Civic Education Journal, 2(2), 8-15. https://journal.unnes.ac.id/sju/index.php/ucej/article/view/2166. (2013)

[10] Twomey, C. R., Shamburg, C., \& Zieger, L. B: Teachers as technology leaders. Eugene, OR: ISTE Publications. 2006

[11] Brooks-Young, Susan: Teaching with the tools kids really use: Learning with web and mobile technologies. Corwin A SAGE Company, California. (2010)

[12] Mukhlasin, A. 2019. "Kepemimpinan Pendidikan Di Era Revolusi Industri 4.0." Jurnal Tawadhu, 3(1), 674-692. https://doi.org/10.13140/RG.2.2.30831.59043. (2019)

[13] Wulandari, F., \& dkk: Kepemimpinan Kepala Sekolah di Era Revolusi Industri 4.0 dalam Meningkatkan Akreditasi Sekolah.” Prosiding Seminar Nasional Pendidikan Program Pascasarjana Universitas PGRI Palembang, 308-312. Retrieved from https://jurnal.univpgripalembang.ac.id/index.php/Prosidingpps/article/download/2539/2366 (2019)

[14] Harris, A.: COVID-19 - School Leadership in Crisis?” Journal of Professional Capital and Community. https://www.emerald.com/insight/publication/issn/2056-9548 (2020)

[15] Netolicky, D.M.: School leadership during a pandemic: Navigating tensions. Journal of Professional Capital and Community. Vol. 5 No. 3/4. (2020)

[16] INSPIRASI: Indonesian school leaders's response to COVID-19. Retrieved from: https://inspirasifoundation.org/wp-content/uploads/2020/05/Indonesia-School-Leaders-Survey-byGSL-INSPIRASI.pdf (2020)

[17] Winchester H., Chesterman C., Lorenzo, S. and Browning L.: The great barrier myth: An investigation of barriers to promotion for academic women staff in Australian universities. www.avcc.edu.au (2005)

[18] Nguyen, Thai Lan Huong.: Barrier to and facilitator of Female Dean's Career Advancement in Higher Education: an Exploratory Study in Vietnam, High Educ, vol 66, pp. 123-138. (2013)

[19] Shahtalebi, Somaye: Women Success Factor From Leadership in Higher Education, Social and behavioral Science, Vol 15, pp. 3644-3647. (2011) 
[20] Kholis, N.: Gender Role and the Effects of Human Capital and Social Capital on Academic Career Success", Conference Paper, diakses pada 14 Juni 2021 dari: https://www.researchgate.net/publication/319766229 (2017)

[21] Aldrich, A.S., Lotito., N.J.: Pandemic performance: Women leaders in the Covid-19 crisis. Politics \& Gender. DOI: 10.1017/S1743923X20000549. (2020)

[22] Wardani, A., Munandar, M. A., \& Makmuri.: Peran Kepemimpinan Kepala Sekolah Perempuan Terhadap Motivasi Kerja Guru (Studi di SMAN 12 Semarang)." Unnes Civic Education Journal, 2(2), 8-15. (2013)

[23] Du Plessis, P.:Challenges for rural school leaders in a developing context: A case study on leadership practices of effective rural principals. KOERS - Bulletin for Christian Scholarship, 82(3). Available at: https:// doi.org/10.19108/KOERS.82.3.2337 (2017)

[24] Hudson, L., Mahendrarajah, S., Walton, M., Pascaris, M.J., Melim, S., Rutterberg-Rozen, R.: Leadership in education during COVID-19: Learning and growth through a crisis. Journal of Digital and Technology. (2020)

[25] Azorín, C.: Beyond COVID-19 supernova. Is another education coming? Journal Of Professional Capital And Community, 5(3/4), 381-390. https://doi.org/10.1108/ jpcc-05-2020-0019. (2020)

[26] Seidman, I.: Interviewing as Qualitative Research: A Guide for Researchers in Education and the Social Sciences. 5th ed. New York, NY: Teachers College Press.(2019)

[27] Salazar, P.S.: The professional development needs of rural high school principals: A seven-state study. The Rural Educator. Volume 28(3). (2007)

[28] Yin, R. K: Case study research and applications. Thousands Oak, CA: Sage Publication. (2016)

[29] Saldana, J.: The coding manual for qualitative researchers. California: Thousand Oaks. (2015)

[30] Miles, M. B., \& Huberman, A. M.: Qualitative data analysis: An expanded sourcebook (2nd ed.). Sage Publications, Inc. (1994)

[31] Ugur, N.G., \& Koc, T.: Leading and teaching with technology: school principals' perspective. International Journal of Educational Leadership and Management, 7(1), 42-71. DOI:10.17583/ijelm.2018.3758. (2019)

[32] Gosmire, D., \& Grady, M. L.: A bumpy road: Principal as technology leader. Principal Leadership, 7(6), p. 15-21). National Association of Secondary Principals. Reston, VA. (2007) 